\title{
Factors associated with depressive symptoms in older adults in context of social vulnerability
}

\author{
Fatores associados a sintomas depressivos em idosos inseridos em contexto de vulnerabilidade social \\ Factores Asociados a los síntomas depresivos en ancianos en contexto de alta vulnerabilidad social
}

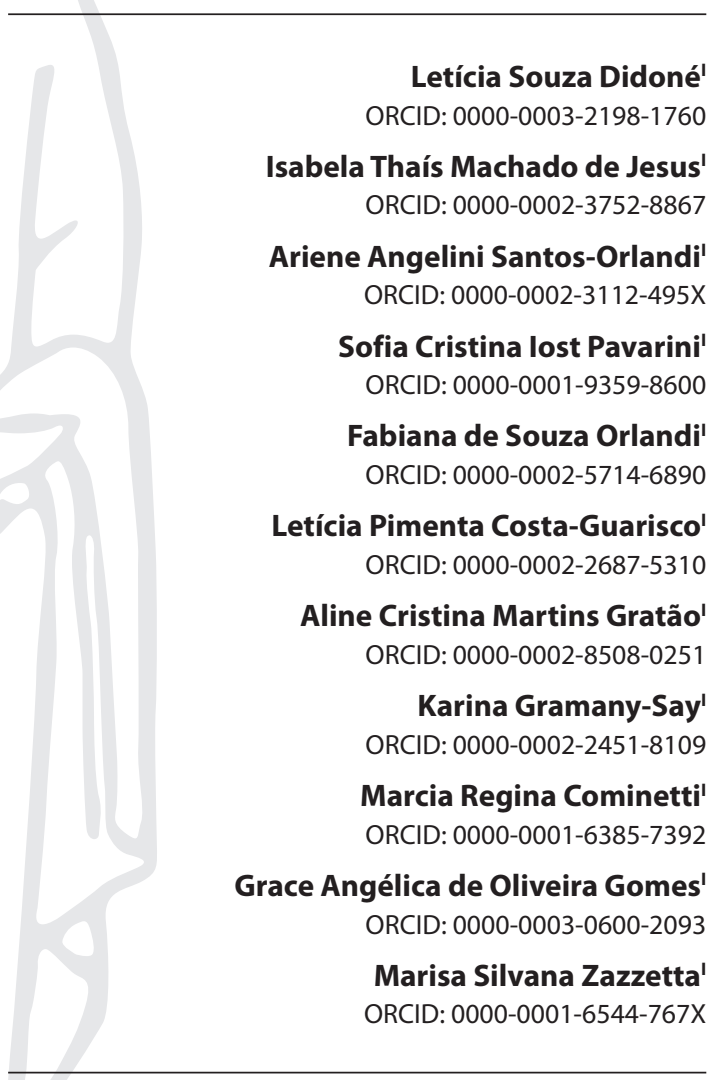

Universidade Federal de São Carlos. São Carlos, São Paulo, Brazil.

How to cite this article:

Didone LS, Machado ITJ, Santos-Orlandi AA, Pavarini SCI, Orlandi FS, Costa-Guarisco LP, et al. Factors associated with depressive symptoms in older adults in context of social vulnerability. Rev Bras Enferm. 2020;73(Suppl 1):e20190107. doi: http://dx.doi.org/10.1590/0034-7167-2019-0107

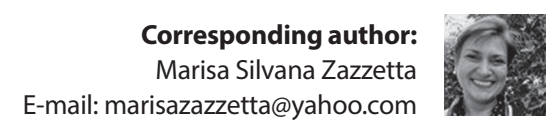

EDITOR IN CHIEF: Antonio José de Almeida Filho ASSOCIATE EDITOR: Hugo Fernandes

Submission: 06-18-2019 Approval: 11-18-2019

\begin{abstract}
Objective: To identify factors associated with depressive symptoms in the elderly inserted in a context of high social vulnerability. Methods: A cross-sectional study was carried out with 302 elderly people enrolled in Primary Care. We used a sociodemographic questionnaire, Geriatric Depression Scale, Mini Nutritional Assessment, Shor-form-6D Quality of Life Questionnaire and Medical Outcome Study Scale. For data analysis, a logistic regression was performed considering two groups, with and without depressive symptoms. Results: A good perception of the quality of life (OR: 0.21$)$ and receiving emotional support (OR: 0.98$)$ were presented as protective factors for depression, have risks of malnutrition (OR: 4.87), belong to the female sex OR: 1.88) and living alone (OR: 2.34), indicated a predictor factor for depression. Conclusion: Quality of life and social support were identified as protective factors for depressive symptoms while being at risk of malnutrition, living alone, reporting pain and being female are predictors.

Descriptors: Depression; Aged; Vulnerable Population; Nursing Care; Geriatric.
\end{abstract}

\section{RESUMO}

Objetivo: Identificar fatores associados a sintomas depressivos em idosos inseridos em contexto de alta vulnerabilidade social. Métodos: Estudo transversal realizado com 302 idosos de comunidade cadastrados em Unidades de Saúde da Família. Utilizou-se questionário sociodemográfico, Escala de Depressão Geriátrica, Mini Avaliação Nutricional, Questionário de Qualidade de Vida Short-Form-6D e Escala de Medical Outcome Study. Para análise de dados foi realizada regressão logística, considerando dois grupos, com e sem sintomas depressivos. Resultados: Uma boa percepção da qualidade de vida $(\mathrm{OR}: 0,21)$ e receber apoio emocional $(\mathrm{OR}: 0,98)$ se apresentaram enquanto fatores protetores à depressão; e ter riscos de desnutrição (OR: 4,87), pertencer ao sexo feminino (OR: 1,88) e morar só $(\mathrm{OR}: 2,34)$ indicaram fator preditor para a depressão. Conclusão: Qualidade de vida e suporte social foram identificados como fatores protetores para sintomas depressivos, enquanto estar sob risco de desnutrição, morar sozinho, relatar dor e ser do sexo feminino são fatores preditores. Descritores: Depressão; Idoso; Vulnerabilidade Social; Enfermagem Geriátrica; Geriatria.

\section{RESUMEN}

Objetivo: Identificar factores asociados a los síntomas depresivos en ancianos insertados en contexto de alta vulnerabilidad social. Métodos: Estudio transversal realizado con 302 ancianos de comunidad registrados en Unidades de Salud de la Familia. Se utilizó cuestionario sociodemográfico, Escala de Depresión Geriátrica, Mini Evaluación Nutricional, Cuestionario de Calidad de Vida Shor-form-6D y Escala de Medical Outcome Study. Para el análisis de datos ha sido realizada regresión logística considerando dos equipos, con y sin síntomas depresivos. Resultados: Una buena percepción de la calidad de vida (OR: 0,21$)$ y recibir apoyo emocional (OR: 0,98) se presentaron como factores protectores a la depresión, tener riesgos de desnutrición (OR: 4,87), pertenecer al sexo femenino (OR: 4,87$)$ OR: 1,88) y vivir solo $(O R: 2,34)$, indicaron factor indicador para la depresión. Conclusión: La calidad de vida y el apoyo social han sido identificados como factores protectores para los síntomas depresivos en cuanto estar bajo el riesgo de desnutrición, vivir solo, relatar el dolor y ser del sexo femenino son factores indicadores

Descriptores: Síntomas Depressivos; Anciano; Vulnerabilidad Social; Enfermería Geriátrica; Geriatría. 


\section{INTRODUCTION}

Old age becomes increasingly representative in Brazil ${ }^{(1)}$. By considering only the municipality of São Carlos, individuals aged 60 and over already represent $11 \%$ of the population ${ }^{(2)}$, while in the national population, they correspond to 13\% (IBGE 2018). The support of Unidades de Saúde da Familia (Family Healthcare Units) for the elderly population is fundamental for the prevention of diseases, health promotion, especially those residing in a context of high social vulnerability. Known as the absence or lack of support from social institutions and associated with the fragility of a group's socioeconomic situation, social vulnerability consists of exposure to the risk of exclusion, lack of material resources, information, opportunities, and rights. It is possible to observe it through social and individual factors, such as education, income, education, access to services, among others ${ }^{(3-5)}$.

The aging process can cause functional losses, increasing vulnerability to chronic illness - for example, depression. Currently, such disease is considered a severe public health problem, as it directly affects the functional capacity of humans and the number of people diagnosed ${ }^{(6-8)}$. Studies characterize it by a set of psychological and physiological symptoms such as persistent sadness, anhedonia, altered appetite and sleep, low self-esteem, insecurity, restlessness, feelings of worthlessness, guilt, anxiety to the point of thinking or practicing self-injury and even suicide ${ }^{(9-10)}$. It is a complex result of the interaction of biopsychosocial factors. People who have experienced adverse events in their lifetime, such as bereavement, violence, unemployment, are more likely to develop the disease ${ }^{(10-11)}$.

According to the World Health Organization (WHO), 300 million people of all age groups are affected worldwide by depression and are considered a critical global public health problem ${ }^{(12)}$. The number of people with anxiety and depression disorders is growing, especially in low-income countries. Brazil is considered the most depressed country in Latin America, with approximately 11.5 million people diagnosed ${ }^{(10-13)}$. By 2030, researches estimate that depression will be the most common disease in the world, affecting more people than any other condition, such as heart disease $^{(10)}$. It is noteworthy that depression in the elderly is difficult to diagnose because, erroneously, its symptoms are easily confused with somatic complaints of a normal aging process. Prepared by the World Health Organization, the 2013-2020 Mental Health Action Plan stresses the importance of promoting mental well-being and preventing mental disorders, providing care, improving recovery, and promoting human rights ${ }^{(14-15)}$. In 2015, the United Nations (UN) adopted the 2030 agenda for Sustainable Development, with 17 objectives. Among them, health and wellbeing are present, and their guidelines point to a commitment to reduce premature mortality from noncommunicable diseases by one third through prevention and treatment, as well as to promote mental health and well-being. To the same end, the UN also emphasizes a more careful look at the developing countries with investment in health and emphasizes early screening for the reduction or management of health risks ${ }^{(16)}$. Therefore, identifying factors associated with depressive symptoms in the elderly in the context of high social vulnerability is important.

\section{OBJECTIVE}

To identify factors associated with depressive symptoms in the elderly in a context of high social vulnerability.

\section{METHODS}

\section{Ethical aspects}

The study derived from the research entitled "Tool for monitoring fragility levels and associated factors in the elderly attended by the Family Health Support Center (NASF) in the municipality of São Carlos". We respected all ethical precepts, according to resolution 466/12 of the Conselho Nacional de Saúde (National Health Council).

\section{Study Design, location, and period}

This study is a cross-sectional study guided by the STROBE tool, whose data collection was performed from January to October 2016, through home interviews with trained and qualified interviewers. All research participants accepted the invitation freely and informed and registered their consent through the Informed Consent Form.

\section{Population, inclusion and exclusion criteria}

The study consisted of a sample of 302 elderly registered in five Unidades de Saúde da Familia (Family Healthcare Units) of a broad region, characterized by a high index of social vulnerability, according to the Índice Paulista de Vulnerabilidade Social (Paulista Social Vulnerability Index ${ }^{(17)}$. We interviewed all the elderly $((\mathrm{n}=$ 302) who met the following inclusion criteria: individuals aged 60 or older, living in neighborhoods in a context of high social vulnerability, and registered in the Unidade de Saúde de Família (Family Healthcare Unit).

We used as exclusion criterion: elderly who did not reach the cut-off number, 13 points, in the Mini-Mental State Examination ${ }^{(18)}$.

\section{Data Collection Instruments}

Sociodemographic data - A section with a semi-structured interview that aimed to collect sociodemographic data regarding gender, age, ethnicity, education, marital status, family income, number of people with whom they live, health perception, and report of pain for over six months.

Geriatric Depression Scale (GDS-15) - To assess depressive symptoms, we used the Geriatric Depression Scale (GDS-15), which consisted of 15 questions that track depressive symptoms. Individuals with reaching 0 to 5 points we considered "without depression index," from 6 to 11 points "presence of mild depressive symptoms" and 11 to 15 points "presence of severe depressive symptoms"(19).

Mini Nutrition Assessment (MNA) - To assess the risk of malnutrition, we applied the Mini Nutrition Assessment (MNA), a questionnaire that considers self-perceived health and nutritional status reported by the elderly themselves. The sum of MNA scores 
goes up to 30 points if the score is higher than 23.5 points, the patient is in a normal state of nutrition if it is lower a nutritional intervention is recommended because the elderly may need a prescription of nutritional supplements ${ }^{(20)}$.

Quality of Life Questionnaire Short-Form-6D (SF-6D) - To verify the perception of quality of life, we applied the Quality of Life Questionnaire Short-Form-6D (SF-6D), which, through 10 questions, assesses eight domains, namely: functional capacity, global limitation, physical aspects, emotional aspects, social aspects, pain, mental health, and vitality. The single score ranges from 0 to 1 , with 0 being the worst quality of life, and 1, the better state of health ${ }^{(21)}$.

Medical Outcome Study Scale (MOS) - In the Social Support assessment, focusing on emotional support, we used the Medical Outcome Study (MOS) scale, consisting of 19 self-rated questions, which evaluate five dimensions. : material, affective, emotional, information support, and positive social interaction. The scale has no cutoff score: the lower the score presented, the lower the social support level of the ${ }^{(22)}$ dimensions.

Katz and Lawton Scale - To assess the basic activities of daily living, we used the Katz Index of Independence in Activities of Daily Living (ADL), which assesses six functions: bathing, dressing, toileting, transferring, continence and feeding ${ }^{(23)}$. The score ranges from 0 to 6 points, with 0 being independent in all six functions. To assess the Instrumental Activities of Daily Living (IADLs), we used a questionnaire that considers seven instrumental activities, namely: using the telephone, traveling, shopping, preparing meals, doing housework, taking medications, and managing money. The score ranges from 7 to 21 points, where the higher the score, the higher the independence: 0 to 7 points, total dependence; 8 to 14 points, partial dependence; and 15 to 21 points, independence ${ }^{(22-23)}$.

International Physical Activity Questionnaire - To measure the level of Physical Activity (FA), we used the International Physical Activity Questionnaire - IPAQ - long-version. The questionnaire is divided into four components: job-related physical activity, transportation physical activity, domestic physical activity, and leisure physical activity. The questions refer to last week's physical activity (last seven days) and measure the number of days and time spent on moderate and vigorous activity in each of the components: those who performed 150 minutes or more of PA during the week were classified as active. , while those who performed less than 150 minutes were rated as insufficiently active ${ }^{(24)}$.

\section{Results analysis and statistics}

We coded the study data and organized it in a database, in double entry and comparison of values, using the Microsoft Excel program. We performed the treatment and data analysis through the statistical program SPSS 20.0 for Windows (Statistical Package for the Social Science). For the analysis of sociodemographic characterization and description of the instrument scores, we used descriptive statistics as measures of central tendency (simple frequency, mean, median, minimum and maximum), and dispersion measures (standard deviation). To verify the association of depression with sociodemographic data, quality of life, social support, nutrition, and presence of pain, we performed multivariate regression. We applied univariate regression with the dependent variable being the presence of depressive symptoms according to the GDS-15 scale, considering two groups, with depression and without depression. Of the variables analyzed in the univariate regression model (method forward), we maintained the variables that presented $p \leq 0.2$. The numerical variables included continuously were: age, years of schooling, social support domains (affective, emotional support, social interaction, information, and positive interaction), basic and instrumental activities of daily living and physical activity assessment. The variables with $p \leq$ 0.05 remained in the multivariate model, being adjusted for the variables "gender," "living alone," "quality of life," "social support" and "nutrition". The significance level for the statistical tests of $5 \%(\mathrm{p}<0.05)$ was adopted.

Chart 1 - Categorization of independent variables used for understanding in regression analysis, São Carlos, Brazil, 2015

\begin{tabular}{|l|l|l|}
\hline $\begin{array}{l}\text { Independent } \\
\text { variable }\end{array}$ & Encoding & Categories \\
\hline Gender & Gender & $\begin{array}{l}\text { Male }=0 \text { (Ref.) } \\
\text { Female }=1\end{array}$ \\
\hline $\begin{array}{l}\text { Nutritional } \\
\text { assessment }\end{array}$ & Nutritional risk & $\begin{array}{l}\text { Normal }=0 \text { (Ref.) } \\
\text { Risk of malnutrition }=1\end{array}$ \\
\hline Living alone & Living alone & $\begin{array}{l}\text { Not living alone }=0 \text { (Ref.) } \\
\text { Living only }=1\end{array}$ \\
\hline $\begin{array}{l}\text { Health } \\
\text { perception }\end{array}$ & $\begin{array}{l}\text { Health } \\
\text { perception }\end{array}$ & $\begin{array}{l}\text { Excellent } / \text { Very good }=0 \text { (Ref.) } \\
\text { Good }=1 \\
\text { Fairly }=2\end{array}$ \\
\hline Quality of life & $\begin{array}{l}\text { Quality of life } \\
\text { perception }\end{array}$ & $\begin{array}{l}\text { Good }=0 \\
\text { Bad }=1 \text { (Ref.) }\end{array}$ \\
\hline Pain & Pain reporting & $\begin{array}{l}\text { Yes }=0 \\
\text { No }=1 \text { (Ref.) }\end{array}$ \\
\hline
\end{tabular}

\section{RESULTS}

The study included 302 elderly, with a mean age of 69.59 years (SD $=7.407)$, mostly female $(56.6 \%)$, white $(41.3 \%)$, with partners $(58,3 \%)$ and level of education from 1 to 4 years $(50.6 \%)$. As for income, the elderly stated that they earn enough to live (51.1\%). The elderly live on average with two people in the house, and only $15 \%$ of respondents live alone. Of the total participants, 111 had depressive symptoms, either mild or severe, showing "good" perception of the quality of life (50.3\%). Regarding social support, the highest average was affective support (88.39\%), risk of malnutrition (52.3\%), and pain reporting for more than six months (74.1\%). Most of the individuals did not have a dependence on basic and instrumental activities of daily living nor have a considerable level of physical activity (greater than 150 minutes/week), as shown in Table 1.

As it is possible to observe in Table 3, having a good perception of quality of life (OR: $0.21 ; 95 \% \mathrm{Cl}: 0.12-0.38)$ and receiving emotional support (OR: 0.98; $95 \% \mathrm{Cl}$ : $0.97-0.99)$ presented as protective factors against depression, while being at risk of malnutrition (OR: $4.87 ; 95 \% \mathrm{Cl}: 1.71-13.85)$, belonging to the female gender (OR: 1.88; 95\% Cl: 1.10-3.20) and living alone (OR: 2.34; $95 \% \mathrm{Cl}: 1.05-5.21)$ indicated a predictor of depression. 
Table 1 - Descriptive variables of elderly registered in Unidades de Saúde da Família (Family Healthcare Units) of a neighborhood in a context of Social vulnerability in the interior of the state of São Paulo, Brazil, $2015(\mathrm{~N}=302)$

\begin{tabular}{|c|c|c|c|c|c|}
\hline Variables & Categories & n (\%) & Mean (sd) & [Min-Max] & Median \\
\hline \multirow[t]{2}{*}{ Gender } & Male & $131(43.3)$ & & & \\
\hline & Female & $171(56.6)$ & & & \\
\hline \multirow[t]{4}{*}{ Age } & & & 69.59 (7.407) & $60-98$ & 68 \\
\hline & $60-69$ & $163(54.0)$ & & & \\
\hline & $70-79$ & $102(33.8)$ & & & \\
\hline & $\geq 80$ & $37(12.2)$ & & & \\
\hline \multirow[t]{6}{*}{ Ethnicity } & White & $125(41.3)$ & & & \\
\hline & Pardo(brown) / Mulatto / Caboclo & $114(37.7)$ & & & \\
\hline & Black & $54(17.8)$ & & & \\
\hline & Yellow(Asian) & $5(1.6)$ & & & \\
\hline & Does not know & $2(0.6)$ & & & \\
\hline & Did not answer & $2(0.6)$ & & & \\
\hline \multirow[t]{3}{*}{ Marital Status } & With partner & $163(58.3)$ & & & \\
\hline & Without partner & $102(33.8)$ & & & \\
\hline & Did not answer & $1(0.3)$ & & & \\
\hline \multirow[t]{3}{*}{ Schooling } & Illiterate & $104(34.4)$ & & & \\
\hline & $1-4$ years of study & $153(50.6)$ & & & \\
\hline & Five years or more & $45(14.9)$ & & & \\
\hline Family Income & & & $1751.09(971.422)$ & $70-8000$ & 1600 \\
\hline Number of members in the same house & & & $2.90(1.59)$ & $10-1$ & 2 \\
\hline \multirow[t]{2}{*}{ Lives only } & Yes & $48(15.8)$ & & & \\
\hline & No & $254(84.1)$ & & & \\
\hline \multirow[t]{4}{*}{ Depressive symptoms } & Without symptoms & $198(65.3)$ & & & \\
\hline & Mild & $86(28.4)$ & & & \\
\hline & Serious & $9(3)$ & & & \\
\hline & Did not answer & $10(3.3)$ & & & \\
\hline \multirow[t]{3}{*}{ Quality of life perception } & Yes & $152(50.3)$ & & & \\
\hline & No & $149(49.3)$ & & & \\
\hline & Did not answer & $1(0.3)$ & & & \\
\hline \multirow[t]{5}{*}{ Social Support } & Material support & & $88.13(24.13)$ & $0-100$ & 100 \\
\hline & Affective support & & $88.39(23.60)$ & $0-100$ & 100 \\
\hline & Emotional interaction & & $84.70(25.36)$ & $0-100$ & 100 \\
\hline & Social interaction support & & $83.10(27.61)$ & $0-100$ & 100 \\
\hline & Information support & & $83.04(27.29)$ & $0-100$ & 100 \\
\hline \multirow[t]{3}{*}{ Nutritional assessment } & Normal & $135(44.7)$ & & & \\
\hline & At-risk & $158(52.3)$ & & & \\
\hline & Did not answer & $9(2.9)$ & & & \\
\hline \multirow[t]{3}{*}{ Pain reporting } & Yes & $224(74.1)$ & & & \\
\hline & No & $68(22.5)$ & & & \\
\hline & Did not answer & $10(3.3)$ & & & \\
\hline Dependency on Activities of Daily Living & & & $0.72(1.62)$ & $0-12$ & 0 \\
\hline Dependency on Instrumental Activities of Daily Living & & & $2.46(3.57)$ & $0-14$ & 1 \\
\hline Physical Activity level & & & $919.91(1.513)$ & $0-118.20$ & 420 \\
\hline
\end{tabular}

Note: Table 1 shows the independent variables that we analyzed using univariate logistic regression to verify an association with depression.

Table 2 - Univariate logistic regression analysis for depression in elderly residents of neighborhoods in a context of social vulnerability in São Carlos, Brazil, 2015

\begin{tabular}{|c|c|c|c|c|c|}
\hline Variables & Category & $p$ value & $\mathbf{O R} *$ & Min & Max \\
\hline Gender & $\begin{array}{l}\text { Male } \\
\text { Female }\end{array}$ & $\begin{array}{c}\text { Ref. } \\
0.009\end{array}$ & $\begin{array}{c}- \\
0.53\end{array}$ & $\overline{0 .}$ & $\overline{-}$ \\
\hline Age & Continuous variable & 0.855 & 0.99 & 0.96 & 1.02 \\
\hline Schooling (years) & Continuous variable & 0.900 & 1.00 & 0.89 & 1.13 \\
\hline
\end{tabular}




\begin{tabular}{|c|c|c|c|c|c|}
\hline Variables & Category & $p$ value & $\mathbf{O R} *$ & Min & Max \\
\hline Quality of life & Continuous variable & 0.000 & 0.00 & 0.00 & 0.03 \\
\hline Material support & Continuous variable & 0.022 & 0.98 & 0.97 & 0.99 \\
\hline Affective support & Continuous variable & 0.002 & 0.98 & 0.97 & 0.99 \\
\hline Emotional support & Continuous variable & 0.001 & 0.98 & 0.97 & 0.99 \\
\hline Social interaction support & Continuous variable & 0.000 & 0.97 & 0.96 & 0.98 \\
\hline Information support & Continuous variable & 0.003 & 0.98 & 0.97 & 0.99 \\
\hline Nutritional assessment & Risk of Malnutrition Normal & Ref. 0.918 & -0.963 & -0.47 & -1.97 \\
\hline Pain reporting & $\begin{array}{l}\text { Yes } \\
\text { No }\end{array}$ & $\begin{array}{c}0.353 \\
\text { Ref. }\end{array}$ & $\begin{array}{c}1.40 \\
-\end{array}$ & $\begin{array}{c}0.68 \\
-\end{array}$ & $\begin{array}{c}2.86 \\
-\end{array}$ \\
\hline Living alone & $\begin{array}{l}\text { Yes } \\
\text { No }\end{array}$ & $\begin{array}{c}0.060 \\
\text { Ref. }\end{array}$ & $\begin{array}{c}1.96 \\
-\end{array}$ & - & - \\
\hline Instrumental activities of Daily Living & Continuous variable & 0.084 & 1.13 & 0.98 & 1.30 \\
\hline Activities of Daily Living & Continuous variable & 0.005 & 1.08 & 1.02 & 1.15 \\
\hline Physical Activity level & Continuous variable & 0.096 & 1.00 & 1.00 & 1.00 \\
\hline
\end{tabular}

Note: * OR (Odds Ratio) = Factors associated with depression. Cl 95\% OR=95\% confidence interval for the risk ratio. Ref.: Reference Level.

Table 3 - Multivariate logistic regression analysis for depression in elderly residents of neighborhoods in a context of social vulnerability in São Carlos, Brazil, 2015

\begin{tabular}{|c|c|c|c|c|c|}
\hline Variables & Category & $p$ value & OR $^{*}$ & Mín & $\begin{array}{l}\text { 95\%Cl } \\
\text { Máx }\end{array}$ \\
\hline Quality of life & Continuous variable & 0.000 & 0.21 & 0.12 & 0.38 \\
\hline Emotional support & Continuous variable & 0.005 & 0.98 & 0.97 & 0.99 \\
\hline Nutritional Assessment & $\begin{array}{l}\text { Normal } \\
\text { Malnutrition Risk }\end{array}$ & $\begin{array}{l}\text { Ref. } \\
0.003\end{array}$ & 4.87 & 1.71 & 13.85 \\
\hline Gender & $\begin{array}{l}\text { Male } \\
\text { Female }\end{array}$ & $\begin{array}{l}\text { Ref. } \\
0.020\end{array}$ & 1.88 & 1.10 & 3.20 \\
\hline Living alone & $\begin{array}{l}\text { No } \\
\text { Yes }\end{array}$ & $\begin{array}{l}\text { Ref. } \\
0.036\end{array}$ & 2.34 & 1.05 & 5.21 \\
\hline Pain reporting & $\begin{array}{l}\text { No } \\
\text { Yes }\end{array}$ & $\begin{array}{l}\text { Ref. } \\
0.331\end{array}$ & $\begin{array}{l}- \\
1.42\end{array}$ & 0.69 & 2.89 \\
\hline
\end{tabular}

Note: * OR (Odds Ratio) = Factors associated with depression. Cl 95\% OR $=95 \%$ confidence interval for the risk ratio. Ref.: Reference Level.

\section{DISCUSSION}

Literature corroborates the sociodemographic data found among the elderly in the present study, that is, a predominantly female, married elderly community, with average years of schooling from one to four years, income from one to two minimum wages ${ }^{(25-28)}$.

In this study, we found evidence that quality of life and social support (emotional support) are protective factors for depressive symptoms. It is possible to find similar data in the international ${ }^{(29-30)}$ and national ${ }^{(31)}$ literature. Two studies, conducted in Hong Kong with Chinese elderly in the community, identified through WHOQOLBREF that poor quality of life was significantly associated with depression. The authors stated that a good quality of life becomes a protective factor for depressive symptoms ${ }^{(29-30)}$. A recent study conducted in Passo Fundo-RS, with 313 older women, evaluated the prevalence of depressive symptoms in older women who attended a referral center, and only $7.1 \%$ of the older women had symptoms. According to the authors, the low percentage of older women with depressive symptoms in this context reflects the importance of being more socially, culturally and accessing information and interaction media, which differs from the elderly inserted in a context of social vulnerability, which is the case of the elderly in this study. This fact is because, in contexts of poverty, there is often a scarcity of these information resources and an overload of health professionals ${ }^{(31-33)}$.

A predictor of depressive symptoms that the present study identified is the risk of malnutrition. Loss of appetite is a symptom of the disease. A study of the FIBRA (Estudo de Fragilidade em Idosos Brasileiros - Study of Fragility in Brazilian Elderly) group with older people in the community described that most of them who reported reduced appetite were underweight, at risk of malnutrition, and one of the interference factors pointed out was depression ${ }^{(34)}$. There are also reports in the literature that food monotony generates nutrient deficiencies that can compromise mood. In a literature review, scholars considered that vitamin B12 deficiency generates a decrease in serotonin, norepinephrine, and dopamine so that the subject with this deficiency has depressive symptoms. Nor did they rule out the lack of vitamin B12 as a consequence of depression. In 1989, Robins cited that the most common causes of malnutrition in the elderly are "9D", one of which was depression ${ }^{(35-36)}$.

A literature review stated that depression is more prevalent in women than in men, regardless of age group ${ }^{(37)}$, which corroborates being a predictor factor stated in the present study. It is possible to link the higher prevalence of depressive symptoms in the elderly female population to several factors, such as hormonal variations during the life cycle (pregnancy and menopause), living longer than men, experiencing more traumatic events, such as mourning, empty nest, among others ${ }^{(38)}$.

In the present study, to live alone associated with depressive symptoms as a predictor factor. According to a study, healthy family ties can help in coping with the undesirable consequences associated with depression. It is noteworthy that it is essential to have a good quality of the family relationship and good social support ${ }^{(38)}$.

Reporting pain and depressive symptoms have been themes commonly associated, especially regarding chronic and low back pain, to the elderly in the community. A study conducted in Minas Gerais concluded that, due to the presence of pain and depressive symptoms, there is a delay and worsening in treatment. Insomnia and sleep problems have also been reported in the elderly who feel pain and have depressive symptoms, corroborating the 
present study, which points out "pain reporting" as a predictor of depressive symptoms ${ }^{(39)}$.

\section{Study Limitations}

The present study has as its limitation the cross-sectional design itself, as it does not make it possible to conclude the causes of the relations found. Also, the scarcity of recent literature on the theme can affect the discussion of the results of nutrition in the elderly with depressive symptoms.

\section{Contributions to nursing, health, or public policy}

It is important to track and know factors that may be protective and predictors for possible screening and prevention of depression. Depression is a public health problem that affects thousands of people. The more accurate the multifactorial look at symptoms by primary care health services, the more likely they are to prevent risks and health problems arising from depression.

\section{CONCLUSION}

It was possible to identify the quality of life and social support as protective factors for depressive symptoms, while being at risk of malnutrition, living alone, reporting pain, and being female are predictive factors.

Tracking down depressive symptoms in the elderly by primary care professionals favors early diagnosis and treatment, aiming to prevent pathology-related injuries and risks.

\section{FUNDING}

We appreciate the financial support provided by Coordination for the Improvement of Higher Education Personnel (CAPES) - Financing Code 001 and to the Ministry of Health and the São Paulo State Research Support Foundation (FAPESP) that funded the research that underpinned this study, by means of research on the Research Program for the Unified Health System (PPSUS) line.

\section{REFERENCES}

1. Instituto Brasileiro de Geografia e Estatística.-IBGE. População brasileira cresce em ritmo acelerado[Internet]. 2018[cited 2018 Oct 23]. Available from: http://saladeimprensa,ibge,gov,br/noticias?view=noticia\&id=1\&busca=1\&idnoticia $=1272$

2. Sistema Estadual de Análise de Dados-SEADE. População e estatísticas vitais [Internet]. 2013 [cited 2018 Oct 23]. Available from: http:// www.seade.gov.br

3. Rossetti ES, Terassi M, Ottaviani AC, Santos-Orlandi AA, Pavarini SCl, Zazzetta MS. Frailty, depressive symptoms and overload of elderly caregivers in a context of high social vulnerability. Texto Contexto Enferm. 2018;27(3):e3590016. doi: 10.1590/0104-07072018003590016

4. Andrew MK. Frailty and social vulnerability. Interdiscip Top Gerontol Geriatr [Internet]. 2015 [cited 2018 Oct 23];41(1):186-95. Available from: https://www.ncbi.nlm.nih.gov/pubmed/26301990

5. Santos-Orlandi AA, Brito TRP, Ottaviani AC, Rossetti ES, Zazzetta MS, Gratão ACM, et al. Profile of older adults caring for other older adults in contexts of high social vulnerability. Esc Anna Nery. 2017;21(1):e20170013. doi: 10.5935/1414-8145.20170013

6. World Health Organization (WHO), No communicable diseases prematurely take 16 million lives annually, WHO urges more action [Internet]. 2015 [cited 2018 Oct 05]. Available from: http://www,whoint/mediacentre/news/releases/2015/noncommunicable-diseases/en/

7. Oliveira DV, Nascimento JRAJ, Lima MCC, Leme DEC, Antunes MD, Bertolini SMMG. Capacidade funcional e qualidade de vida em mulheres idosas praticantes e não praticantes de hidroginástica, Rev Rede Enferm Nordeste [Internet]. 2017[cited 2018 Oct 24];18(2):1-12. Available from: http://periodicos.ufc.br/rene/article/viewFile/19236/29953

8. Fried LP, Ferruci L, Darer J, Williamson JD, Anderson G. Untangling the concepts of disablity, frailty and comorbidity: implications for improved targeting and care, J Gerontol Ser A Biol Sci Med Sci, 2004;59(3):255-63. doi: 10.1093/GERONA/59.3.M255

9. American Psychiatry Association (APA). Diagnostic and statistical manual of mental disorders - DSM-5 [Internet]. 2014[cited 2018 Oct 05]. Available from: https://www.psychiatry.org/psychiatrists/practice/dsm

10. Organização Pan-Americana da Saúde (PAHO) - Organização Mundial da Saúde (OMS): Folha Informativa de Depressão, atualizada em março de 2018 [Internet]. 2018[cited 2018 Oct 24] Available from: https://www,paho,org/bra/index,php?option=com_content\&view=article \&id=5635:folha- informativa-depressao\&ltemid=822

11. Aguiar AMA, Marques APO, Silva EC, Costa TR, Ramos RSPS, Leal MCC. Prevalência e determinantes de sintomatologia depressiva em idosos assistidos em serviço ambulatorial. Rev Bras Geriatr Gerontol. 2014;17(4):853-66. doi: 10.1590/1809-9823.2014.13198

12. Blas E, Kurup AS. Equity, social determinants and public health programmes [Internet]. Geneva: WHO; 2010 [cited 2019 Aug 10]. Available from: https://apps.who.int/iris/handle/10665/44289

13. Ramos GCF, Carneiro JA, Barbosa ATF, Mendonça JMG, Caldeira AP. Prevalência de sintomas depressivos e fatores associados em idosos no norte de Minas Gerais: um estudo de base populacional. J Bras Psiquiatr. 2015;64(2):122-31. doi: 10.1590/0047-2085000000067

14. World Health Organization. Mental health action plan 2013-2020.Geneve: World Health Organization [Internet]. 2013 [cited 2018 Oct 24]; Available from: http://apps.who.int/iris/ bitstream/10665/89966

15. Hajjar R, Gaudenci Nardelli G, Gaudenci EM, da Silva Santos, Á. Sintomas depressivos e fatores associados em idosos na Atenção Primária à Saúde. Rev Rede Enferm Nordeste [Internet], 2017[cited 2018 Oct 24];18(6):727-33. Available from: http://www.redalyc.org/articulo.oa?id=324054583004 
16. Organizações das Nações Unidas (ONU), Agenda 2030 para o Desenvolvimento Sustentável; Saúde e Bem-Estar [Internet]. 2015[cited 2018 Oct 24]. Available from: http://www.agenda2030.com.br/ods/3/

17. Fundação SEADE. Distribuição da população, segundo grupos do IPVS [Internet]. São Paulo, 2010[cited 2018 Oct 24]. Available from: https:// ipvs.seade.gov.br/view/index.php

18. Bertolucci PHF, Brucki SMD, Campacci SR., YARA, K. O Mini-Exame do Estado Mental em uma população geral: impacto da escolaridade. Arq Neuro-Psiquiatr [Internet]. 1994[cited 2018 Nov 26];52(1):01-07. doi: 10.1590/S0004-282X1994000100001

19. Yesavage J, Brink TL, Rose TL, Lum O, Huang V, Adey M, et al, Development and validation of a geriatric depression screening scale: a preliminary report, J Psych Res. 1986;17(1):37-40.

20. Guigoz Y, Vellas J, Garry P. Mini Nutritional Assessment: a practical assessment tool for grading the nutritional state of elderly patients, Facts Res Gerontol 4, 1994;(supp. 2):15-59.

21. Gonçalves AC, Bruscato AB, Bosi MF, Mesquita RC. Validity of the SF-6D index in Brazilian patients with rheumatoid arthritis. Clin Exp Rheumatol [Internet]. 2009 [cited 2019 Aug 10] 27:237-45. Available from: http://www.clinexprheumatol.org/pubmed/find-pii.asp?pii=19473563

22. Ferraiuoli C, Ferreira SMRR. O outro lado da "Melhor Idade": depressão e suicídio em idosos. Perspect Online, Ciênc Hum Soc Aplic. 2017. doi: $10.25242 / 88767182017821$

23. Katz S. Studies of illness in the aged: the index of ADL: a standardized measure of biological and psychosocial function. Jama, 1963. 185(12):914-9.

24. Lino VTS. Adaptação transcultural da escala de independência em atividades da vida diária (Escala de Katz). Cad Saúde Pública. 2008;1 (24):103-12.

25. Santos RL, Virtuoso JS. Confiabilidade da versão brasileira da Escala de Atividades Instrumentais da Vida Diária. Rev Bras Promoç Saúde. 2008;21(4):290-96.

26. Nunes DP Validação da avaliação subjetiva de fragilidade em idosos no município de São Paulo: estudo SABE. 2011. 108 p. Dissertação Faculdade de Saúde Pública, Universidade de São Paulo, São Paulo.

27. Chaves ECL, Paulino CF, Souza VHS, Mesquita AC, Carvalho FS, Nogueira DA. Qualidade de vida, sintomas depressivos e religiosidade em idosos: um estudo transversal. Texto Contexto Enferm. 2014;23(3):648-55. doi: 10.1590/0104-07072014001000013

28. Tavares DMS. Quality of life and self-esteem among the elderly in the community. Ciênc Saúde Coletiva, 2016;21(11):3557-64. doi: $10.1590 / 1413-812320152111.03032016$

29. Instituto Brasileiro de Geografia e Estatística (IBGE) Síntese de indicadores sociais: uma análise das condições de vida da população brasileira: 2016 / IBGE, Coordenação de População e Indicadores Sociais. - Rio de Janeiro: IBGE, 2016,146 p. - (Estudos e pesquisas. Informação demográfica e socioeconômica, n. 36). ISSN 1516-3296.

30. Chan SW, Chiu HF, Chien WT, Thompson DR, Lam L. Quality of life in Chinese elderly people with depression. Int J Geriatr Psychiatr. 2006;21:312-8. doi: 10.1002/GPS.1461

31. Cao W, Guo C, Ping W, Tan Z, Guo Y, Zheng J. A Community-Based Study of Quality of Life and Depression among Older Adults. Int J Environ Res Public Health. 2016:13(7):693. doi:10.3390/IJERPH1307069

32. Piani MC, Alves ALS, Bervian J, Graeff DB, Pancotte J, Daring M, et al. Prevalência de sintomas depressivos em idosos de um centro de Referência de Atenção ao idoso no município de Passo Fundo, Rio grande do Sul. Rev Bras Geriatr Gerontol. 2016;19(6):930-8. doi: $10.1590 / 1981-22562016019.150211$

33. Souza WC, Mascarenhas LPG, Grzelczak MT, Tajes Jr D, Brasilino FF, Lima VA. Exercício físico na promoção da saúde na terceira idade. Saúde Meio Ambiente. 2015;4(1):55-65. doi: 10.24302/sma.v4i1.672

34. Borges LJ, Benedetti TRB, Xavier AJ. Fatores associados aos sintomas depressivos em idosos: Estudo Epi Floripa. Rev Saúde Pública. 2013;47(4):701-10. doi: 10.1590/S0034-8910.2013047003844

35. Assumpção D, Borim FSA, Francisco PMSB, Neri AL. Fatores associados ao baixo peso em idosos comunitários de sete cidades brasileiras: Estudo FIBRA. Ciênc Saúde Coletiva. 2018;23(4):1143-50. doi: 10.1590/1413- 81232018234.17422016

36. Robbins LJ. Evaluation of weight loss in the elderly. Geriatrics. 1989;44(4):31-4

37. Lima CM, Barros NS, Barroso BMA, Pereira ACD, Silva APV. Um estudo sobre Depressão na Terceira Idade, 2015. Rev Inova Saúde;7(1)1-13. doi: 10.18616/IS.V7I1.4258

38. Holtfreter K, Reisig D, Turanovic J, Depression and infrequent participation in social activities among older adults: the moderating role of high-quality familial Ties, Aging Mental Health. 2014;379-388, doi: 10.1080/13607863.2015.1099036

39. Figueiredo VF, Pereira LSM, Ferreira PH, Pereira AM, Amorim JSC. Incapacidade funcional, sintomas depressivos e dor lombar em idosos. Fisio Movimento. 2017;26(3):549-57. doi: 10.1590/S0103-51502013000300008 